\title{
Richard Blundell receives IZA prize in labor economics
}

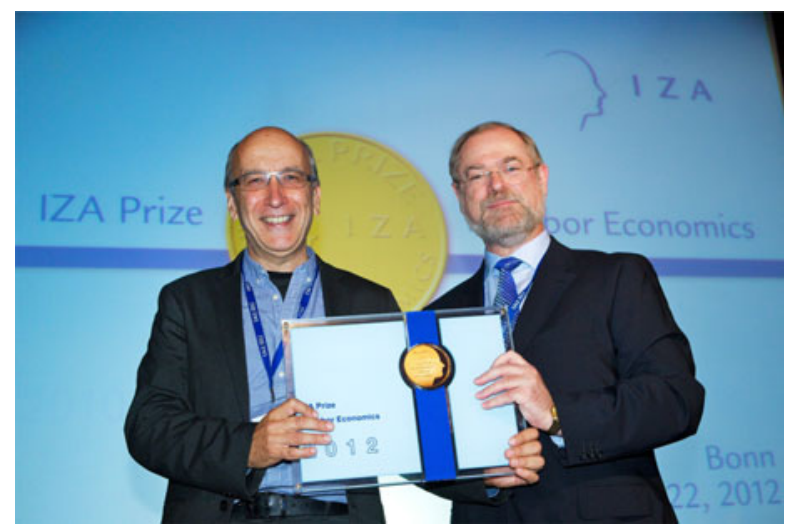

Richard Blundell (left) with IZA Director Klaus Zimmermann at the IZA Prize ceremony

This year's IZA Prize in Labor Economics was awarded to Richard Blundell (University College London and Institute for Fiscal Studies (IFS)). The prestigious award recognizes his path-breaking contributions to the econometric analysis of labor markets and public policy reforms.

Richard Blundell holds the David Ricardo Chair of Political Economy at University College London. He is a graduate of the University of Bristol and London School of Economics. Since 1986 he has been the Research Director of the IFS, where he is also the Director of the ESRC Centre for the Microeconomic Analysis of Public Policy. He has been on the editorial board of many academic journals and is also one of the editors of the Mirrlees Review of Tax Reform which reported its findings in 2011. In a similar spirit, IZA recently proposed a tax reform concept for Germany, which is based largely on the methodology developed by Richard Blundell. 
The Prize was presented on September 22 during the Annual Conference of the European Association of Labour Economists hosted by IZA in Bonn. "Richard is a role model to many researchers across the globe. His work is a remarkable combination of academic excellence and policy relevance," said Klaus F. Zimmermann, Editor-in-Chief of the Journal of Population Economics, in his function as the IZA Director. The Prize Committee included US Nobel laureate George A. Akerlof (University of California, Berkeley), as well as Marco Caliendo (University of Potsdam), Richard Portes (London Business School), Jan Svejnar (University of Michigan, Ann Arbor), and IZA Director Klaus F. Zimmermann.

The IZA Prize in Labor Economics has been awarded annually since 2002 by the Institute for Study of Labor, an international research institute and think tank based in Bonn, Germany. Awarded for outstanding contributions to the advancement of labor economics and worth 50,000 euros, the IZA Prize is considered the most prestigious science award in labor economics worldwide. Previous laureates include Dale Mortensen and Christopher Pissarides, who later received the Nobel Prize in Economics. More information on the Prize can be found at www.iza.org.

\section{Award statement}

The 2012 IZA Prize in Labor Economics is awarded to Richard Blundell (University College London and IFS) for his path-breaking contributions to the econometric analysis of labor markets and public policy reforms. Professor Blundell has played a major role in the development of modern labor and policy analysis. His work is characterized by a focus on pressing questions in economic policy, the development of cutting-edge econometric methods to tackle such questions, and painstaking analysis of micro data. Blundell's contributions laid the foundations for the modern economic analysis of labor supply, consumer behavior, and policy reforms. His work has been enormously influential in the worldwide debates about tax and welfare reforms over the past decades.

Richard Blundell has provided some of the most significant contributions to the econometric analysis of labor supply. Among his early work was a seminal paper with Richard Smith in which they provided a novel test for endogeneity in econometric models (Econometrica, 1986). The test signified a crucial advancement in addressing important empirical questions, for instance, regarding the relationship between household income and female labor supply. Richard Blundell's work has greatly enhanced our understanding of how taxation and social policy influence individuals' labor market behavior. Blundell did not only help develop a new theoretical framework for understanding labor supply reactions to policy changes. He also complemented the theoretical analysis by developing the necessary instruments for careful empirical analysis, and he applied these tools to real-world policy questions. His paper with Alan Duncan and Costas Meghir (Econometrica, 1998) is exemplary of this approach. The authors developed novel methods to examine how household labor supply 
responds to tax reforms and used these methods to estimate the reactions to the UK policy reforms in the 1980s.

Richard Blundell also made fundamental contributions to studying labor supply and consumer demand in an integrated, unifying framework. His approach offered a dynamic perspective, taking into account that consumption smoothing over the life cycle and labor supply are inherently linked. More recently, Blundell has also been concerned with economic inequality and the changes in income distributions. He made important methodological contributions that have advanced the econometric modeling of such dynamic issues. Furthermore, Blundell was among the first to explicitly take individual-level heterogeneity into account when assessing actual policy problems.

In addition to his academic contributions, Richard Blundell has made a compelling case for more evidence-based research and policy advice. He has taken a leading role in demonstrating the importance of giving researchers enhanced access to micro data for their research. Throughout his career, Blundell has intensely engaged in the policy debate. From 2006 until 2011, he served as a coeditor of the influential Mirrlees Review. In this role, he provided practical recommendations for improving UK tax policy and helped develop the pillars of an efficient modern tax system. His enduring commitment to research and policy makes Blundell a role model for combining academic strength with policy relevance.

Richard Blundell currently holds the David Ricardo Chair of Political Economy at University College London and is the Research Director of the Institute for Fiscal Studies, where he is also the Director of the ESRC Centre for the Microeconomic Analysis of Public Policy. He is the Commander of the British Empire, a Fellow of the Econometric Society and of the British Academy, and an Honorary Member of the American Economic Association and the American Academy of Arts and Science. In 1995, he was awarded the Yrjö Jahnsson Prize for his work in microeconometrics, labor supply, and consumer behavior; in 2000, he received the Frisch Medal by the Econometric Society for his 1998 Econometrica paper with Alan Duncan and Costas Meghir. Blundell has delivered numerous distinguished lectures, and he holds honorary doctoral degrees from the Universities of St. Gallen, Bergen, and Mannheim. He is the current president of the Royal Economic Society and past president of the Econometric Society, the European Economic Association, and the Society of Labor Economists. He also served as coeditor for journals such as Econometrica, the Journal of Econometrics, and the Review of Economic Studies.

The IZA Prize in Labor Economics 2012 honors the work of an eminent scholar who has greatly shaped our view on labor market analysis and economic policy. 